\title{
Ingham and Keynes on the Nature of Money
}

\author{
M G Hayes \\ September 2012

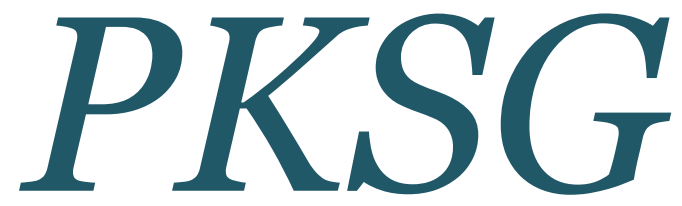 \\ Post Keynesian Economics Study Group
}

Working Paper 1209

This paper may be downloaded free of charge from www.postkeynesian.net

2012 C M G Hayes

Users may download and/or print one copy to facilitate their private study or for non-commercial research and may forward the link to others for similar purposes. Users may not engage in further distribution of this material or use it for any profit-making activities or any other form of commercial gain. 


\title{
Ingham and Keynes on the Nature of Money
}

\begin{abstract}
This paper compares and contrasts the thinking of Keynes and Geoffrey Ingham, focussing mainly on The General Theory and Ingham's The Nature of Money (2004). Two points in particular are addressed: first, the relevance of Ingham's insistence (following Keynes, among others) on the primacy of money of account to an understanding of Keynes's own insistence that income is intrinsically monetary and upon the importance of the wage unit as an analytical tool; and second, the subtle contrast between Keynes and Ingham in their understandings of the source of interest as a genuinely monetary and not a 'real' phenomenon. Where Keynes identifies uncertainty as the source of interest within a methodologically individualistic framework of analysis, Ingham offers a sociological case in terms of the struggle between the debtor and creditor interests that inevitably emerge as a result of the creation of bank money under capitalism. Taking both points together, Ingham's work not only underpins the crucial distinction between money and 'real' wages for the theory of employment but also develops Keynes's recognition of the potential opposition between the interests of finance and industry.
\end{abstract}

Keywords: nature of money - nature of income - theory of interest

JEL classifications: B22 B31 E01 E42 E43

M. G. Hayes, Robinson College, Cambridge CB3 9AN, United Kingdom.

Email: mgh37@cam.ac.uk 


\section{Ingham and Keynes on the Nature of Money}

\section{G. Hayes}

\section{Introduction}

In 1933, Keynes wrote of the need for a monetary theory of production, that is a theory of production and value in a monetary economy (Keynes, 1933). He argued that the distinction between a barter and a monetary economy, traditionally made by economists, needed to be recast as one between a real-exchange economy (a fictional theoretical construct created by economists) and the monetary economy we actually observe. A real-exchange economy may use money as a means of exchange (the characteristic traditionally attributed to a monetary economy) but the role of money is neutral, a simple go between in a relation between things, more efficient than barter, which drops out on consolidation when we consider the economy as a whole. Rather Keynes sought a theoretical conception of the observable market economy which recognises, as anything but neutral, the essential role of money in its operation. While modern mainstream economics has continued to construct ever more mathematically sophisticated real-exchange models, Geoffrey Ingham has remained consistently faithful to Keynes's call for a genuine monetary theory. The originality of Ingham's work partly derives from his mastery of the two disciplines of economics and sociology and his insistence on reuniting these twins separated by the shipwreck of the Methodenstreit of the German Historical School. In an exemplar of interdisciplinary work, he has not only preserved Keynes's key insights but strengthened the foundations of the theory of interest in the historical, cultural and institutional roots at which Keynes no more than hinted.

This chapter will compare and contrast the thinking of Keynes and Ingham, focussing mainly on The General Theory (Keynes, 1936, G.T. in page references) and Ingham's The Nature of 
Money (2004). The limits of the author's knowledge and ability, being a scholar of Keynes (and The General Theory in particular) rather than of Ingham, make this more of a reflection on The General Theory from the perspective of Ingham's work than the reverse. Two points in particular will be addressed: first, the relevance of Ingham's insistence (following Keynes, among others) on the primacy of money of account to an understanding of Keynes's own insistence that income is intrinsically monetary and upon the importance of the wage unit as an analytical tool; and second, the subtle contrast between Keynes and Ingham in their understandings of the source of interest as a genuinely monetary and not a 'real' phenomenon. Where Keynes identifies uncertainty as the source of interest within a methodologically individualistic framework of analysis, Ingham offers a sociological case in terms of the struggle between the debtor and creditor interests that inevitably emerge as a result of the creation of bank money under capitalism. Taking both points together, Ingham's work not only underpins the crucial distinction between money and 'real' wages for the theory of employment but also develops Keynes's recognition of the potential opposition between the interests of finance and industry.

\section{On the nature of money and the monetary nature of income}

At the core of Ingham's conception of the nature of money is an understanding that money arises from a legally enforceable contractual relationship between a debtor and a creditor, whether the debtor is voluntary, as in the case of a bank loan, or involuntary, as in the case of taxation. The unit of account in which the contract is denominated is not arbitrary in the manner that mainstream economics suggests, that any standardisable good may act as counter or numeraire, e.g. burgers or chocolate bars. Furthermore the unit of account need not be the means of payment or exchange, as Ingham makes abundantly clear in his discussion of 
medieval money. Ultimately the unit of account is defined in Chartalist terms, by relation to whatever thing the state will accept in payment of taxes, something which includes debts of the state itself contracted in that unit of account.

Ingham's understanding of the nature of money clearly owes a great deal to Keynes's thought in A Treatise on Money (Keynes, 1930). The first connection to be made with Keynes's later work, The General Theory, is that income, like money itself, is also a matter of contract for money value. This does not mean that income is a flow of money, even if that is how most of us as individuals experience it. On the contrary, it is vital that income be understood as the value of output. Yet a great deal hangs on what we mean by 'value' and 'output'. Despite Keynes devoting 38 pages (nearly $10 \%$ of The General Theory) to the problem of defining income and its relation to saving and investment (G.T. pp. 37-40, 52-85), Hansen states: 'The section on Income is of no great importance for an understanding of The General Theory and may quite well be omitted if the student so wishes.' (Hansen, 1953, p. 54). Then he, and nearly everyone else since, proceeds to write the symbol $Y$ to denote real income, without realising that by doing so they undermine Keynes's central argument about the nature and source of involuntary unemployment in a competitive economy.

If output were truly homogeneous, so that it might properly be represented by a single number, the central argument of The General Theory would fail. Keynes's principal policy aim in this book was to discredit the prescription of aggregate wage cuts as a remedy for unemployment and his argument hinges on the distinction between money and real wages. If employers and workers bargain in real terms, e.g. over quantities of corn, there can be no denying that if workers are prepared to accept their marginal production of corn as their wage, they can all be profitably employed. Keynes's point is that employers and workers 
bargain in money terms and that, even under perfect competition, the real wage is neither determined in, nor clears, the labour market. The labour contract is not a barter contract in which labour services exchange for goods. The payment of wages in money is essential and decidedly not neutral.

The backbone of The General Theory (to be found in its chapter 3) is the principle of effective demand, following which the level of aggregate employment is determined by the income expected by employers. This principle represents a conception of the competitive equilibrium of the economy as a whole, a system equilibrium, quite different from the general equilibrium of real-exchange economics. It is this different notion of equilibrium that permits the theory to explain the existence of involuntary unemployment. Yet Keynes's principle can be articulated only if a precise meaning can be given to income as a measurable quantity.

In chapter 4 of The General Theory Keynes explains why income cannot be measured in real, physical terms. His point can be illustrated as follows. A farmer starts with one tractor, a ton of diesel, and half a ton of seedcorn. She ends with one slightly older tractor, half a ton of diesel, seven tons of corn, and five tons of straw. What is her net output? No answer is possible without assigning prices to each type of good. Thus income is an intrinsically monetary concept in that it requires prices denominated in some unit of account. The measurement of money income is a matter of accounting and for the most part income is 'recognised' (in the technical sense) when goods are delivered in fulfilment of a contract for money value. The consumption of capital goods raises some difficult technical issues, which Keynes addresses through his concept of user cost, but these are not issues of principle.

There are two reasons, one theoretical and the other practical, why we need to have some measure of 'real' income, even though it has no direct physical counterpart. Employment is a 
sufficient proxy for output for the purpose of defining the principle of effective demand in chapter 3. Nevertheless, when Keynes turns to the detailed theory of aggregate demand (one side of effective demand, in conjunction with aggregate supply), he introduces the consumption function, which relates consumption to income and not employment, and the multiplier relationship between consumption and investment. Accordingly he needs a measure of income which is a close proxy for employment, a measure of real income ('in some sense', G.T. p. 91) which can also be related to consumption, saving and investment. His solution is to introduce the wage unit, the money wage of a unit of standard labour (e.g. the minimum wage per hour). Income expressed in wage units rather than units of currency remains money income but redenominated to take account of inflation in the money wage and therefore the general price level of consumption goods. More subtly, the measurement of the key variables of Keynes's theory in terms of wage units means that they are not directly affected by changes in the money wage. The effects of a policy of wage cuts can then be isolated and analysed through its influence on the independent variables of Keynes's theoretical system (as he sets out in his chapter 19).

The practical reason for a measure of 'real' income is the need for data in the conduct of economic policy. Perhaps the most well-known economic statistic is the rate of growth of the volume measure of Gross Domestic Product (GDP). Such a measure is calculated by adjusting money income, not by a single price such as the wage unit, but by an index, the average price of a basket of goods. An index is a useful statistic but it is not the basis for exact causal analysis and in this case encourages the mistake that output or real income can be represented by a single number. As Keynes puts it beautifully, 
To say that net output to-day is greater, but the price-level lower, than ten years ago or one year ago, is a proposition of a similar character to the statement that Queen Victoria was a better queen but not a happier woman than Queen Elizabeth - a proposition not without meaning and not without interest, but unsuitable as material for the differential calculus. Our precision will be a mock precision if we try to use such partly vague and non-quantitative concepts as the basis of a quantitative analysis. (G.T. p. 40)

Another aspect of the importance of the contractual nature of income is demonstrated by the investment-saving identity and the related 'loanable funds' fallacy. Despite Keynes having devoted so much effort to defining income and its consequence in terms of the equality of the values of aggregate investment and saving, many economists persist in the view that an imbalance of some kind between saving and investment can affect the rate of interest. This is a further example of real-exchange economic thinking that breaks down when applied to the observable monetary economy.

The idea that interest is the price that clears the market for loanable funds can only make sense in a non-monetary, corn model with a single form of homogeneous output that can be consumed, stored (saved) or planted (invested). Corn can also be borrowed at interest, an exchange of future corn for present. After harvest there is a certain quantity of corn in the granaries. Farmers demand corn for investment in planting seed including wages for the next season. The corn wage is determined in the labour market so that all available workers are employed if they are willing to accept their marginal product. The distribution of the existing stock of corn need not correspond to the farmers' investment requirements so that there is a demand for loans of corn. Similarly some people may wish to consume in excess of their current stock and wages and some may wish to save. The supply of corn for lending is thus given by the stock in granaries in excess of the amount required for consumption out of wages (farmers themselves having the choice between investing and lending) and the demand 
for loans of corn is driven by farmers seeking to invest and people in general wishing to consume between now and the next harvest an amount in excess of their wages and current holding.

Assuming that the planting of seed corn faces diminishing returns, competition will drive the corn rate of interest to the level at which the investment demand equals the amount of the corn stock that people are willing not to consume but lend. Even if consumption decisions are insensitive to the interest rate, investment can adjust in line with the marginal productivity of capital (planted corn). Thus the interest rate is determined by the balance between productivity and thrift and an increase in thrift will reduce the interest rate. Note that there is nothing here to stop the corn interest rate becoming negative. Since corn is costly to store, through losses by disease, infestation or theft, the loanable funds market may clear at an interest rate below zero, such that farmers are paid by savers to invest so that savers may defer consumption.

The mistake in loanable funds theory is to think that nothing changes when output is heterogeneous, so that money can be treated as another commodity like corn. To treat the market economy as a corn economy is not an abstraction but a fiction, or at best a description only of very limited and particular historical circumstances of no relevance today. We have already noted that the payment of wages in money means that production and income are determined by effective demand and not by the availability of labour and other factors of production at a given real wage. Thus saving does not come into being (placed in the equivalent of granaries) and then seek an outlet in investment, as in the corn model; rather investment and saving are determined simultaneously. 
An additional source of the confusion in economic thinking has been the near universal adoption of the concept of an income-expenditure rather than the investment-saving identity. Income and expenditure are equal only if the consumption of goods in production or the adding of goods to inventories are treated as a form of expenditure, even when no sale takes place. However, this redefinition of terms is not harmless. The notion of the incomeexpenditure identity leads people to draw diagrams of a circular flow with goods and services going one way and flows of money the other way. Income is thereby confused with money flows, and money with saving, opening the door to the idea that saving and money balances can be combined as loanable funds and tacitly reintroducing a corn theory of interest.

Income arises from the fulfilment of an agreement to deliver newly produced goods or services for a price expressed in terms of the money of account, thereby creating a money debt. The debt may be discharged on delivery, after a period of credit or even before delivery (in effect, where a deposit is paid), yet either way the creation of income and saving is independent of the payment of money. All that is required is a contract price expressed in terms of the money of account and the debt can be discharged by any number of monetary media which bear a fixed relation to the money of account. Once the contracts have been made, there is no means by which a change in the terms on which money is available to settle debts can alter the balance between saving and investment. Those terms enter at a logically anterior stage, into the decisions to make contracts for the delivery of consumption and investment goods.

Investment does not require saving, but finance i.e. holdings or loans of money, the creation of which does not involve production. Indeed, as Ingham emphasises, the creation of money by the banking system is an intrinsic part of the dynamic of capitalism. There can be no 
disequilibrium between saving and investment (even in an open economy, given the appropriate definition of terms) and the source of money interest must be found elsewhere.

\section{Ingham and Keynes on the nature of money and interest}

At first glance Ingham has relatively little to say about the rate of interest and Keynes relatively little to say about the value of money, or general price level. Most of Keynes's analysis of the nature of money in The General Theory is contained in chapter 17, of which Hansen this time writes: 'not much would have been lost if it had never been written' (1953, p. 159)! Keynes here addresses the reasons for the dominance of the money rate of interest in the determination of investment, employing a method of analysis very neoclassical in flavour. Ingham's primary interest is in the conditions for the establishment and maintenance of a stable money, which is partly a matter of the maintenance of its purchasing power, and the level of interest rates becomes an indicator of the balance of power between the debtor and creditor interests. Yet the two approaches complement each other and Ingham sheds light on matters which Keynes touches upon but does not develop.

\section{Liquidity and abstract value}

Having escaped the shackles of loanable funds thinking, Keynes presents a theory of interest as the price of overcoming liquidity preference, the propensity to hoard money. The rejection of Keynes's theory and consequent persistence of loanable funds thinking in modern macroeconomics owes much to the difficulty of chapter 17 and of the meaning and significance of liquidity in Keynes's thought, about which even post-Keynesians do not agree. Kaldor (1939, p. 4, n 5) noted that by liquidity Keynes did not mean simply convertibility (i.e. ease of sale without loss). Keynes's only explicit definition is to be found in A Treatise on Money, where he defines (in passing) a liquid asset as 'more certainly 
realisable at short notice without loss' (1930, p. 59). By the time we reach chapter 17 of The General Theory, Keynes appears to place the emphasis on the words 'more certainly' in his Treatise definition, as the degree to which the value of an asset, measured in any given standard, is independent of changes in the state of expectation. The nature of liquidity and the rate of interest are for Keynes bound up with uncertainty about the unknowable future.

Although such fundamental uncertainty plays no overt role in Ingham's work, he shares with Mirowski a central concern with 'the working fiction of a monetary invariant through time, so that debt contracts (the ultimate locus of value creation ...) may be written in terms of the unit at different dates' (Mirowski, 1991, p. 580). The stability or predictability of value is the key attribute of money with which both Keynes and Ingham are concerned.

When Keynes refers to liquidity (other than in section V of chapter 17), he really does mean money, including short-term bank and state debts the value of which is not sensitive to changes in the rate of interest because of the short period to redemption (G.T. pp. 166-167). He regards the 'liquidity' (note the inverted commas) of financial securities as an illusion and something distinct from true liquidity (G.T. pp. 153, 155, 160). Listed equity securities offer high convertibility but low liquidity. This puts Keynes to some extent at odds with his followers Joan Robinson, Minsky and Davidson, all of whom envisage some degree of substitutability between money and securities in terms of liquidity. Keynes even suggests that in some historical environments (not specified, but presumably those in which Ingham notes the absence of the conditions for a stable money, such as medieval Europe), land has been the dominant liquid asset, despite its obvious lack of easy convertibility (G.T. p. 241).

In section $\mathrm{V}$ of chapter 17 , Keynes considers what liquidity might mean in a non-monetary economy. He defines such an economy not in terms of the absence of a money of account but 
in terms of the absence of an 'asset for which the liquidity premium is always in excess of the carrying costs' (G.T. p. 239). It is clearly impossible for him to envisage an economy without some form of money of account; even during the Weimar hyperinflation, people continued to use the Reichsmark as currency, even if by the barrow-load. Nevertheless medieval Europe provides examples of societies without banks or bonds and with a shortage of coinage, i.e. with insufficient monetary media in which to store money value, and the German hyperinflation is a case where money had lost its liquidity premium and acquired significant carrying costs. This leads to what appears to be a general definition of liquidity as follows:

In [a non-monetary] economy capital equipments will differ from one another (a) in the variety of the consumables in the production of which they are capable of assisting, (b) in the stability of value of their output (in the sense in which the value of bread is more stable through time than the value of fashionable novelties), and (c) in the rapidity with which the wealth embodied in them can become 'liquid', in the sense of producing output, the proceeds of which can be re-embodied if desired in quite a different form. (G.T. p. 240)

Liquidity is firstly a function of the degree to which a capital asset can be used in the production of different consumables, so that a change in the expectation of its yield based on production in one line can be met by switching to another line. The prospective yield on the second line is lower than originally expected from the first, but higher than now expected from the first after the change in the state of expectation, reducing the impact of the change on the value of the asset. Keynes then refers to the importance of the stability of the value of the consumables produced. Stability in this context means independence from changes in the state of long-term expectation (e.g. he does not consider bread to be a fashion item). The third element of his definition is the 'turnover period', the period over which the asset can be converted through production into consumable output. The shorter the period, the less likely 
is it that a change in the state of expectation will arise during the life of the asset. Clearly Keynes is here thinking in aggregate terms: although an individual investor can always exchange an asset for money, its convertibility for the community as a whole depends on its conversion into consumption goods through production and not just exchange.

The case of a non-monetary economy illustrates that liquidity means lasting, immediate command over an indefinite basket of consumption goods and services, which is as close as an economist can get to the concept of abstract value. As for the curious example of liquid land, we can note that in an agricultural economy land is the primary capital asset and source of output, both directly and through feeding and equipping the artisans and servants who produce the consumption goods and amenities enjoyed by the wealthy. Thus the ownership of land represents a secure autarkic claim on a stream of consumption, the value of which is determined by technical and natural relationships that are robust in the face of a weak state and undeveloped monetary system. Land represents the ultimate safe asset in such a society. Nevertheless the purpose of this mainly hypothetical discussion of the non-monetary economy is to articulate the meaning of the liquidity provided, in modern society, by money.

\section{Liquidity preference and the conventional rate of interest}

Keynes's theory of interest is driven by the interaction between uncertainty about the future rates of interest on long-term bonds and the precautionary and speculative demands for money, what are often called 'idle balances' because they are not based on the requirements of the production and distribution of output. Keynes's formal representation of this (in terms of the schedule of liquidity preference) is a short-term explanation which hinges on the relationship at any time between the market rate of interest and what the market thinks is a 'safe' rate of interest, i.e. the rate which is likely to prevail in the long term. Keynes is 
explicit (G.T. pp. 201-204) that the safe rate of interest is a convention, such that the rate can be managed down by an astute central bank or it can rise sharply in the event of a sudden loss of confidence. This led to the criticism by Hicks (1939) that the rate of interest is left hanging by its own bootstraps. What this really represents is the limits of purely economic theory based on methodological individualism, which hankers after a 'natural' rate of interest grounded in the Classical balance between productivity and thrift. The question of what determines the rate of interest in the long term cannot be answered without the help of sociology.

In Ingham's theory, the rate of interest is an outcome of the balance of forces between debtor and creditor interests, where this balance is not a unique mechanical equilibrium but rather the uneasy, indeterminate position of the marker in a Weberian tug-o'-war. This struggle cannot be understood without reference to the forces determining the supply of money, about which Keynes says little in The General Theory, in contrast to the extensive treatment of $A$ Treatise on Money. Since money is intrinsically a matter of debt, it is unsurprising that its quantity should reflect the forces governing the creation of new debtor-creditor relations. In Keynes's short-term liquidity preference theory of interest, the action is all on the demand side and supply is taken as given by the state of banking policy, a compound of the terms on which the central bank will make reserves available and of the reserve requirements and lending policies of the banking system. The exogeneity of the money supply in The General Theory means only that the money supply is determined by the decisions of the monetary sector and not by those of the productive sector, even if the monetary sector may choose to accommodate an increased demand for credit by an increase in the money supply. Even if at times this accommodation may be fairly automatic, as some post-Keynesian economists 
maintain, it is a mistake to regard the monetary sector as simply the passive partner of the productive sector. Keynes recognises, even if in this context he makes little reference to, the active role of banking in the emergence and continuous renewal of capitalism.

In section VII of chapter 21 of The General Theory, Keynes briefly addresses the issues considered in more depth by Ingham. Following a formal exposition of the short-term channels by which the quantity of money influences the price level in the light of the principle of effective demand, he discusses whether a simpler relationship (along the lines of the traditional quantity theory) might exist in the long term. Prefacing his remarks with the statement that 'this is a question for historical generalisation rather than pure theory' (G.T. p. 306), he suggests that a rough relationship between money and prices arises from two opposing tendencies of a sociological character. On the one hand, there may be a limit on how much money people will hold idle, provided that the rate of interest exceeds a certain figure, where both the limit and the minimum rate of interest are grounded in psychology. If the supply of money and the rate of interest exceed these figures, the rate of interest will fall and the price level will eventually tend to rise, although discontinuously and not in accordance with any mathematical function. On the other hand, if there is a persistent shortage of money, society will tend to respond by devising new ways of creating money, since the alternative of cutting wages and the price level has unpalatable consequences in terms of labour unrest and bankruptcy by debt deflation.

Keynes argues that the $19^{\text {th }}$ century represented on average a socially tolerable combination of investment opportunities, interest rates, price level and employment. He describes a balance of forces between employers and workers over money wages and between debtor and creditor interests ('flexibility and conservatism') over financial innovation. The loss of this 
balance after the first world war resulted in unacceptable levels of unemployment and pressure for major political changes, which indeed came to pass in the aftermath of a second war. Western governments then took responsibility for full employment and (to varying degrees) for social welfare in the settlement leading to what is seen, in retrospect, as a Golden Age of economic growth from 1950-1973.

Ingham (2004) elaborates and extends Keynes's sketch with a detailed historical analysis ranging from ancient Babylon to the Maastricht treaty. He argues that the inter-war period during which Keynes wrote saw a discrediting of free markets such that at Bretton Woods the bankers were not even invited. The new system was designed to promote production, employment and trade and to reduce money to the basic functions of medium of exchange and payment that the textbooks allow, preventing speculation in currencies and sovereign bonds through the regime of fixed exchange rates and capital controls. For a while, countries were free to set interest rates in line with the needs of domestic full employment policy, yet the stability and prosperity of the Golden Age, based on an uneasy compromise between industry, finance and labour brokered by a strong state, contained the seeds of its own destruction.

In Ingham's narrative, the power of bankers grew with the successful expansion of industry and their own efforts to create and exploit loopholes in the capital control regime, fuelled by the growth of Eurodollar balances supplied by the US trade deficit. In the UK, the policy of industrial merger and rationalisation, aimed at technical innovation and industrial competitiveness, backfired as both industry and labour acquired monopoly power over price and wage setting, beyond the control of state incomes policies. The 1970s saw the breakdown of Bretton Woods and the transition to a new consensus of which a central plank was 'sound 
money' within a framework of competitive markets, with the control of inflation rather than full employment restored as the main priority of the state, and financial capital unfettered. Sound money largely means 'dear money and easy credit' (Tily, 2007). Inflation was to be controlled initially by monetarism, involving savage hikes in interest rates and severe recession in output. Monetarism with its black box appeal to the quantity theory was gradually replaced by the more intellectually respectable inflation targeting and its central concept of the natural rate of unemployment. This means in practice that whatever level of output and unemployment is consistent with a stable rate of inflation must be considered natural. Meanwhile financial services flourished in the absence of capital controls, providing credit for almost anything other than productive industrial investment, which remains financed almost entirely by industrial cashflow. The primacy of the rentier interest was reestablished and consolidated by the doctrine and practice of independent central banking, reaching its apogee in the creation of the European Central Bank (ECB).

Ingham's 2004 discussion of the Euro project is almost prophetic. He notes the uniqueness of the monetary union in combining a common currency with independent national budgets. The effect, if not the intention, he argued then, had been to transfer power to the financial markets. The ECB's sole concern with price stability, combined with the Stability and Growth Pact, meant that member states had to pre-finance their spending like any private corporation. The meaning of a budget deficit had changed: a deficit was no longer possible without a credit line from the markets. Events since 2010 have proven the accuracy of this analysis. Interest rates are a matter of the balance of bargaining power between state and creditor and of conventional notions of creditworthiness in which ratings agencies have played an ignoble part. As for the future, Ingham wrote in 2004 that 'the logic of the situation 
suggests - but of course can never determine - that [the EU] regains the power by placing its money in the hands of a sovereign body' (2004, p. 196).

\section{Conclusion}

Reflecting on Ingham's work creates in this author a sense of how impoverished economics has become (and I dare say sociology weakened, in a different way) as a result of the enforced separation of the two disciplines created, or at least represented, by the Methodenstreit and compounded by the 1980s counter-reformation in macroeconomics. Ingham's 2004 analysis of the Euro project reads with extraordinary prescience in 2012. It appears that mainstream academic macroeconomics has, by its elevation of technique over substance and confusion of abstraction with fiction, become incapable of providing useful policy analysis and, at worst, no more than a rhetorical weapon for libertarian ideologues. It should come as no surprise that the dominant influences on recent economic performance are essentially political and sociological in character: the Bretton Woods system and its demise, the acceptance and then renunciation by government of responsibility for full employment, the rise and fall of political trade unionism, the resurgence of monetarism followed by independent central banking combined with financial liberalisation, the subsequent bailout of the banking system and the new austerity. Yet mainstream macroeconomists continue to build models in which governments simply waste resources, trade unions create unemployment and banks do not figure at all, based upon the fiction of the neutrality of money within a real-exchange framework.

Ingham, like Keynes, is a stickler for insisting that the logical foundations of an argument must be secure. In Keynes's case, the mistaken premise that real output can be measured by a single number leads to the metaphysical idea of the real wage as a causal variable, a price that 
clears the market for labour as a whole. Keynes insists that, in a monetary economy with a division of labour, wages are always and necessarily a matter of contract for money value, and the real wage (which one, indeed?) is simply the resultant of the money wage and an arbitrary index of product prices. The conflation of money and real wages represents a fundamental flaw in reasoning, a failure to grasp macroeconomic thinking and a breach of the scientific method of constructing theory using only variables that have (potentially) observable empirical counterparts.

In Ingham's case, he insists that the conventional tale of money evolving from a convenient means of exchange is a just-so story that obscures the role of the state and lacks historical support. The distinction between means of payment and means of exchange may seem trivial or pedantic to the superficial observer, like that between money and real wages, yet it has farreaching consequences. The commodity theory of money distorts the interpretation of the historical record and provides a misleading basis for economic policy. The neglect of the true nature of money has serious consequences in the ill-founded policy of financial liberalisation that has led to precisely the type of financial crises predicted by Ingham as long ago as 2004 . There is more to sociology than economics and the influences upon Ingham's work include Weber, Knapp and Simmel as well as Keynes and more recent post-Keynesian economists such as Wray and Smithin. Nevertheless, as outlined above, the text of The General Theory itself identifies clearly where the interface between economics and sociology on this topic should lie and the high degree of consistency between the work of Keynes and Ingham. Unlike mainstream economists, Keynes was willing to admit the limits of economics and accept that the rate of interest could not be reduced to an apolitical, technical matter. It is true that The General Theory lacks the rich detail of Ingham's examination of the forces 
governing the production and value of money, such as the fiscal power of the state and the active role of the banking system as an entrepreneurial force in capitalism, highlighted by Schumpeter. Keynes's task is the narrower one of identifying the technical flaws in realexchange economics and the true nature of those relationships between the quantitative, measurable variables of employment, income, interest, money and prices that are amenable to a mathematical treatment. Even his analysis is contingent upon the social institutions of early $20^{\text {th }}$ century capitalism and it would be as much a mistake for post-Keynesian economists to over-generalise The General Theory as it is for mainstream economists to claim their models have universal application across time and culture.

Thus Ingham joins Keynes among the ranks of deep thinkers who delve down to the very roots of social science and insist that, without sound intellectual foundations, public policy will continue to be driven simply by the balance of power between rival interests. Or worse, theory itself is suborned and becomes merely a rhetorical tool in the political struggle.

\section{References}

Hansen, A. H. (1953) A Guide to Keynes, New York: McGraw-Hill.

Hicks, J. R. (1939) Value and Capital, Oxford: Clarendon Press.

Ingham, G. K. (2004) The Nature of Money, Cambridge: Polity Press.

Kaldor, N. (1939), 'Speculation and economic stability', Review of Economic Studies, 7, 127.

Keynes, J. M. (1930) A Treatise on Money, London: Macmillan, in D. E. Moggridge (ed.), The Collected Writings of John Maynard Keynes, vols. V and VI, 1971. 
Keynes, J. M. (1933) 'A monetary theory of production', in Der Stand und die nächste Zukunft der Konjunkturforschung: Festschrift für Arthur Spiethoff, reprinted in D. E. Moggridge (ed.), The Collected Writings of John Maynard Keynes, vol. XIII, pp. 408-11, 1973.

Keynes, J. M. (1936) The General Theory of Employment, Interest and Money, London: Macmillan, in D. E. Moggridge (ed.), The Collected Writings of John Maynard Keynes, vol. VII, 1973.

Mirowski, P. (1991) 'Postmodernism and the social theory of value', Journal of Post Keynesian Economics, 13, 565-82.

Tily, G. (2007) Keynes's General Theory, The Rate of Interest and 'Keynesian' Economics: Keynes Betrayed, Basingstoke: Palgrave Macmillan. 